\title{
My year as interim
}

\author{
Six things I learned for free
}

by Gail Munde

D uring the 1997-98 school year, I served as interim director of a medium-sized academic library. ${ }^{1}$ This was not a career possibility I had anticipated, nor was it one for which I felt suitably prepared, given just 18 months' experience as the library's associate director. However, nothing really prepares anyone to assume leadership of a particular library, as each is as unique as its parent university and its faculty body.

With the library's faculty and staff, I began to adapt to the director's announcement in August that he would be leaving a month later.

In the division of Academic Affairs at East Carolina University, a person who agrees to serve in an interim position may not apply for that position, the rationale being that a noncandidate interim is not tempted to use the time to "audition" or bargain for the advantage of support from the faculty, and thereby remains free to make the inevitable unpopular decisions.

I doubt this arrangement is the norm, but in my case it served notice to all that neither did I wish to be a candidate, nor was there any but the faintest chance that I might become director by default, should the vacancy become unduly prolonged through failed searches.

Knowing this to be a rare learning opportunity, I offer these reflections on my year as interim to those who may be, or may become, interim directors, and also in the hope of being useful to those who are considering directorship as a career goal.
1 The interim director never sleeps.

Well, hardly ever. I was used to working long hours, but not across such sustained periods of time. Because it was a particularly busy year (or it seemed so), there was no letting up and no real time away from the office. I was surprised to find the work much more exhausting and stressful, even the familiar tasks, than that of an associate director.

Looking back, I wish I had been in better physical shape and had more stamina, and I wish I had delegated more. At the time I thought I had to do everything personally; that it might be perceived as weakness or lack of will if I did not assume complete responsibility for everyone and everything. I know this now to be the mistake of a rookie. The interim has a short time frame in which to prove her or his mettle, but needs to resist the urge to be all and do all. Rome really wasn't built in a day, or even in a school year.

\section{Accepting an interim directorship re- quires that one step into the breech.} You assume final responsibility, but only for a limited time. This brevet status forces the interim to deal with the short-term and emergency needs, but not to make decisions that will have long-term or permanent effect, or commit the budget much beyond a fiscal year. The interim is restricted to making only those promises that can be delivered immediately and to setting only those goals that can be met swiftly. 
This binds the interim to what many see as the less-rewarding and routine tasks of leadership, i.e., dealing with the day-to-day personnel problems and disputes, which take up a shocking amount of time and energy; approving nonrecurring expenditures of the operating budget; and adjusting existing policy to fit the conditions without making radical changes.

I never got over the knowledge that I wasn't the "real director" in terms of the work that "real directors" do: casting a clear vision of where the library should go and how it should get there, and getting everyone to go along on the trip. This would be the job of someone who existed only as a cover letter and vita in the growing stack of applications for our open position; and I felt duty-bound, no matter how sorely I was tempted, to make only those decisions that would not tie the hands of the director yet to come.

This special caretaker status, this "leading in limbo," is the hallmark of the interim experience. Even those who serve as interim while they are candidates for the position risk "crash and burn" if they act upon their truest vision during the interim period.

\section{The interim may not see her- or $\mathcal{C h i m s e l f}$ as powerful, but the library fac-} ulty and staff do. There may be times that the interim period is seen as a fresh opportunity for faculty and staff to forward their pet agendas, or to ask that their wishes be granted by the "fairy godmother" interim. This is natural for those with genuine and deeply held beliefs about what would improve the library's position and services, but in some cases, the attempt to take advantage of substitute leadership was transparent. Although I'm sure I was a disappointment to some, most faculty and staff were sympathetic toward my position, and adopted a generous and forgiving attitude toward my mistakes.

\footnotetext{
1 speaking of mistakes, you will make them. In fact, you will discover your weaknesses and inadequacies very quickly, just as if you had taken a crash course titled, "Forget Thinking Everything You Thought You Knew About How to Be the Director." As interim, you may as well resign yourself to this, forgive yourself in advance, and recognize that, most likely, there will be no next time to "do it right" during the tenure as interim.
}

Oddly enough, this was the most rewarding part of the interim experience for me, and the most aggravating. You learn from the mistakes immediately-in that quick, head-slapping kind of realization-but you will probably not have a second chance to apply that learning or to demonstrate to anyone what you have learned.

You may believe you look like a dope to everyone, and it is frustrating to be the only one who knows you are a far wiser dope than before. Unfortunately, there is no other way to begin learning the duties and responsibilities of a director's position without actually taking them on, but fortunately, an interim director's position comes with some insurance.

\section{5}

You have a powerful new boss, probably a vice chancellor or vice provost, who will protect you from your faculty, and when possible, from yourself. This person wants you to succeed and appreciates your willingness to step up and take over what is the great anomaly among the schools and colleges in academe-the library.

The library director is a difficult vacancy to fill on an interim basis, and one for which there is no cognate department or school from which to draw an interim, unless there happens to be a school of library and information science. The interim director must come from another division library, such health sciences or medicine, the library school, or from the academic library itself.

This new boss should offer as a minimum, protection and support for the interim library director. In my institution, the vice chancellor for academic affairs, to whom the library director reports, was extremely gracious and took pains to provide me with every opportunity for exposure to, and participation in, the day-to-day business of academic affairs. He provided what amounted to an internship experience by including me in all academic affairs meetings, deans' and directors' deliberations, university administrative council meetings, and all ceremonial and social occasions. I was able to make and retain valuable relationships across the university that would not necessarily have been possible, or even appropriate, in my role as an associate library director.

(continued on page 420) 
to write about. This short process takes the student one step closer to integrating the various sources they've read. If this working bibliography were paired up with a statement outline, the student can again cut and paste the supporting notes or quotations into the outline and begin drafting.

\section{The plagiarism epidemic}

The online research environment seems to have opened the door to a new wave of plagiarism problems. A larger problem is that often students do not know they are plagiarizing when they simply restate something they've read without providing the source of the information.

Making students aware of plagiarism and how to avoid it is an important part of teaching them the ethics of research. One way of doing this might be to require students to turn in a working bibliography in which they list their sources immediately followed by the notes, quotations, or questions. Students might also be encouraged to think of this part of the process as writing down what they have learned from each source. Anytime they have learned something new, they should give proper credit to that source in the final paper. This gives students the opportunity to separate their own arguments and conclusions from the information gleaned through research. ${ }^{1}$

Developing the research habit of writing from a working bibliography will teach students to use technology to do better research and writing. In this case, technology is actually used to engage the critical thinking skills students need to be effective writers and researchers.

\section{Note}

1. Basic guidelines for creating a working bibliography can be found in the $M L A$ Handbook for Writers of Research Papers, $5^{\text {th }}$ ed. (New York: Modern Language Association of America, 1999)
("My year..." cont. from page 417)

This was an irreplaceable opportunity to step outside the library proper and consider its role and rank within the university's greater structure, as well as to meet and learn from experienced colleagues who were not librarians.

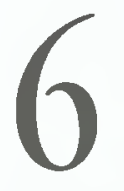

The playing field becomes the university, not the library. One decision you have to make about whether you aspire to being a "permanent" library director is whether you want to swim in this much, much larger pond. If you enjoy the challenges and rewards of librarianship per se, then the director's role may not be one you should seek. Having been associate director to two directors and having served as interim director, this desire to operate on a broader field seems to me the singular difference between being an associate director and being the director.

Skill, knowledge, experience and preparation are important prerequisites, but the true mark of a director is that she or he is not happiest in any other role. It sounds almost too simple, but I'd bet that most library directors would say that directorship has been their career goal right from library school.
The "vision thing" is not just hype. It is real and immutable to the person who is only fulfilled when creating that which doesn't exist, rather than when managing that which already exists.

I recommend the interim experience without reservation to all who would aspire. The opportunity comes along rarely in one's career and it should not be missed. For me, it was a learning experience for which there can be no substitute, an irreplaceable course in self-discovery and a chance to measure myself against the larger yardstick.

\section{Note}

1. East Carolina University is a constituent institution of the University of North Carolina system and serves an enrollment of 17,800 students. Academic Library Services consists of the main library, Joyner Library, and a branch Music Library. During this period, the collection size was $1,030,000$ volumes $/ 5,500$ periodical subscriptions and the library employed 27 faculty members and 76 staff members. The library is managed collegially by the director and a tenured faculty body according to the Faculty Manual and the library's Code of Operations. 